\title{
Horticulture and Health in the Middle Ages: Images from the Tacuinum Sanitatis
}

\author{
Jules Janick ${ }^{1}$ \\ Department of Horticulture and Landscape Architecture, Purdue University, 625 Agriculture Mall Drive, \\ West Lafayette, IN 47897-2010 \\ Marie Christine Daunay \\ INRA, UR1052 Unite de Génétique et d'Amélioration des Fruits et Légumes, F84140, Montfavet, France \\ Harry Paris \\ Department of Vegetable Crops and Plant Genetics, Agricultural Research Organization, Newe, \\ Ya'ar Research Center, P.O. Box 1021, Ramat Yishay 30-095, Israel
}

Additional index words. Ibn Butlan, medieval horticulture, nutrition

\begin{abstract}
Lavishly illustrated late 14th century manuscripts known as the Tacuinum Sanitatis, a guide for healthy living, were based on an 11th century Arabic manuscript known as the Taqwim al-Sihha bi al-Ashab al-Sitta (Rectifying Health by Six Causes) written by the physician and philosopher Ibn Butlan (d. 1063). The expensive, illustrated Tacuinum Sanitatis tomes portray a utopian feudal society in which nobles are engaged in play and romance while feudal laborers work the estate. Rich in horticultural imagery, they include vivid scenes of the harvest of vegetables, fruits, flowers, and culinary and medicinal herbs. Each scene is accompanied by a brief summary of the health aspects of the subject. Although medieval medicine was based on ancient philosophical concepts of Greek sciences, particularly Hippocrates and Galen, these documents connect vegetables and fruits with human health and well-being, similar to modern medicine. Hence, the present-day focus on the connection between horticulture and health can be seen as an extension of ancient and medieval regimens for a healthy lifestyle.
\end{abstract}

The relationship between plants and human health has been and continues to be of great concern for humankind based on both diet and medicinal uses. In this article, we present and analyze images and associated text of an illustrated manuscript from the late Middle Ages, known as the Tacuinum Sanitatis, that provides information on the interrelationship of horticulture and health (Daunay et al., 2009; Janick et al., 2009; Paris et al., 2009). We further compare modern and medieval feelings about the role of horticultural plants and health.

\section{IBN BUTLAN AND MEDIEVAL MEDICINE}

The course of medieval medicine as it relates to horticulture can be followed in the career of a Baghdad-born Nestorian Christian physician and philosopher who died in 1068 (Fig. 1). Ibn Butlan, full name Abu al-Hasan alMukhtar ibn al-Hasan ibn 'Abdun Ibn Sa'dun ibn Butlan, was born and educated in Baghdad but traveled widely to localities that are today in Iraq, Syria, Egypt, Israel, and Turkey (Elkhadem, 1990). In a fascinating footnote in the history of medieval medicine, Ibn Butlan is remembered for a famous dispute with $\mathrm{Ibn}$ Ridwan, chief physician to the Caliph of Cairo, that delved around the question posed whether

Received for publication 14 July 2010. Accepted for publication 3 Sept. 2010.

This paper was part of the workshop "Horticulture and Health: Historical Resources" held 26 July 2009 at the ASHS Conference, St. Louis, MO, and sponsored by the History of Horticultural Science (HIST) Working Group.

${ }^{1}$ To whom reprint requests should be addressed; email janick@purdue.edu. a chicken is of a warmer nature than the chick. The issue concerned the philosophic question of warmth and movement often discussed in Aristotelian science as an exercise for experts and a conundrum for students (Braziller and Conrad, 1995). The controversy between the young, ambitious, and disputatious Ibn Butlan and the elder, temperamental, and meanspirited Ibn Ridwan ended up as a bitter polemic. Ibn Ridwan took offense at anyone who was not an Egyptian or did not strictly adhere to classical orthodoxy. Ibn Butlan's strivings to make a name for himself in a new city where egg production was an important activity turned into a disaster, resulting in a professional boycott. He left Cairo for Constantinople and ended his days in a cloister in Antioch.

Ibn Butlan, however, is best known for his work entitled the Taqwim al-Sihha bi al-Ashab al-Sitta (Rectifying Health by Six Causes), which became an influential treatise on hygiene and dietetics. The Taqwim was a synthesis of the long tradition of ancient Greek medicine and was essentially a guide for healthy living. It summarized in tabular form information on some 280 health-related items, in particular food and especially vegetables and fruits. Widely popular in the Arabic world, it stressed preventive medicine. A French translation (Elkhadem, 1990) exists of the original Arabic text.

The Taqwim summarized information concerning food, and especially vegetables and fruits, in a tabular form that was easy to understand and use. It emphasized that a balanced lifestyle was the prerequisite to prevent disorders and diseases. Ibn Butlan coordinated the doctrine of the six "non-naturals" of Galen by detailing 280 health-related items, their names, their natures according to the four elements, the degree, the best variety, the usefulness, the noxious effects and contraindications, the remedies to the noxiousness, the humors produced, the proper temperaments, the season, the age, the country, the authorities cited, and additional notes.

A Latin translation of the Taqwim commissioned by the Court of Sicily, and completed in 1266, was to become known as the Tacuinum Sanitatis (Tables of Health). It was essentially a medieval handbook on health and wellness. One hundred years later the first illuminated copies of the Tacuinum Sanitatis were commissioned by Giangaleazzo Visconti, the Count of Milan in the Po Valley in northern Italy (Hoeniger, 2006), as expensive gift volumes. The lavishly illustrated volumes portray a utopian feudal society in which nobles are engaged in play and romance while feudal laborers work the estate (Bertiz, 2003; Bovey, 2005; Cogliati Arano, 1976; Hoeniger, 2006; Mane, 2006; Opsomer-Halleux, 1991; Segre Rutz, 2002; Witthoft, 1978). Rich in horticultural imagery, they include vivid scenes of the harvest of vegetables, fruits, flowers, and culinary and medicinal herbs. Each scene is accompanied by a brief summary of the health aspects of the subject that derives from the Taqwim of Ibn Butlan. These documents connect vegetables and fruits as well as the garden itself with human health (Bertiz, 2003). Their advice was intended for the elite and intelligentsia of their epoch.

\section{THE ILLUSTRATED TACUINUM SANITATIS MANSCRIPTS}

A dozen Tacuinum Sanitatis manuscripts have survived, of which six have full-page illustrations (Table 1) and are considered archetypical (Paris et al., 2009). They are 


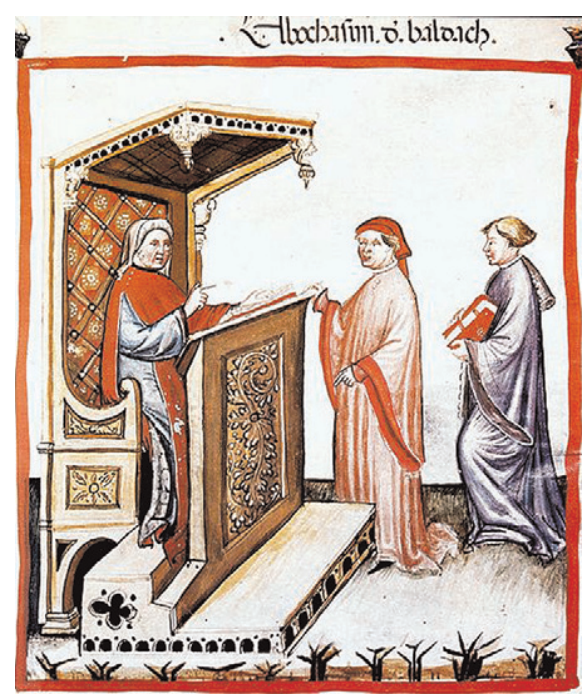

Fig. 1. Ibn Butlan from the Vienna Tacuinum Sanitatis folio $4 \mathrm{r}$.

located in libraries in Austria, Belgium, France, Italy, and Spain. Four of them can be viewed online (http://mandragore.bnf.fr/html/ accueil.html; http://bibliotheque.rouen.fr and http://www.casanatense.it) and a number of facsimile editions have been published. These six copies provide a rich source of information on agriculture and horticulture of the late medieval period containing vivid images of plants being harvested in fields and gardens.

The images of the Tacuinum Sanitatis recensions include some plants of the Taqwim supplemented with those grown in northern Italy during the late 14th century. The plant images depict harvest, emphasizing when the horticultural product has reached the proper stage for consumption. One manuscript (Cod. Ser. N. 2644) in the Osterreichische Nationalbibliothek contains the most accurate depictions and will be the source of most of the plant images presented here. It includes 26 vegetables, 33 fruits, three flowers, 21 culinary and medicinal herbs, and one mushroom (truffles) in addition to nine cereals. Although botanical inaccuracies and lack of detail obscure precise identification in some cases, the imagesalthough in many cases idealized - are, overall, of far better quality than those of most medieval manuscripts. In this article, we present illustrations of four vegetables, four fruits, and four culinary herbs along with the associated health information provided in the Latin text that is derived from the Taqwim.

\section{Vegetables}

Cucumber. Native to India, the first cucumber reached Europe in the medieval period (Paris et al., 2009). In Figure 2A, a welldressed couple examines yellow cylindrical fruit from a viney plant. Identification of the plant is based on the tuberculate (warty) surface of the fruit, a diagnostic feature of cucumber. The bipartite label Cucumeres et citruli can be traced back to Table 10, Line 66 of the Taqwim, the Arabic being al-qitha (chate melon) $w a$ (and) al-khiyar (cucumber),

Table 1. The six archetypical manuscripts of the Tacuinum Sanitatis.

\begin{tabular}{lllc}
\hline Text reference & \multicolumn{1}{c}{ Catalog no. } & \multicolumn{1}{c}{ Depository } & \multicolumn{1}{c}{ Date $^{\mathrm{z}}$} \\
\hline Paris 1673 & Nouv. Acq. Lat. 1673 & Bibliothèque Nationale de France, Paris & $1380-1390$ \\
Liège 1041 & Ms. 1041 & Bibliothèque de l'Université de Liège & $1380-1400$ \\
Vienna 2644 & Cod. Ser. N. 2644 & Osterreichische Nationalbibliothek, Vienna & $1390-1400$ \\
Rome 4182 & Ms. 4182 & Biblioteca Casanatense, Rome & $1390-1400$ \\
Paris 9333 & Latin 9333 & Bibliothèque Nationale de France, Paris & $1445-1451$ \\
Rouen 3054 and & Ms. 3054 (Leber 1088) & Bibliothèque municipale, Rouen, and & 1450
\end{tabular}

Liechtenstein $^{\mathrm{y}}$ private collection

${ }^{2}$ Dates are according to Bovey (2005), Cogliati Arano (1976), Hoeniger (2006), Opsomer-Halleux (1991), and/or Segre Rutz (2002), and/or respective depository catalogs.

${ }^{y}$ The Rouen 3054 and Liechtenstein manuscripts are actually two parts of the same Tacuinum manuscript separated from one another in the 19th century (Bertiz, 2003; Bovey, 2005).
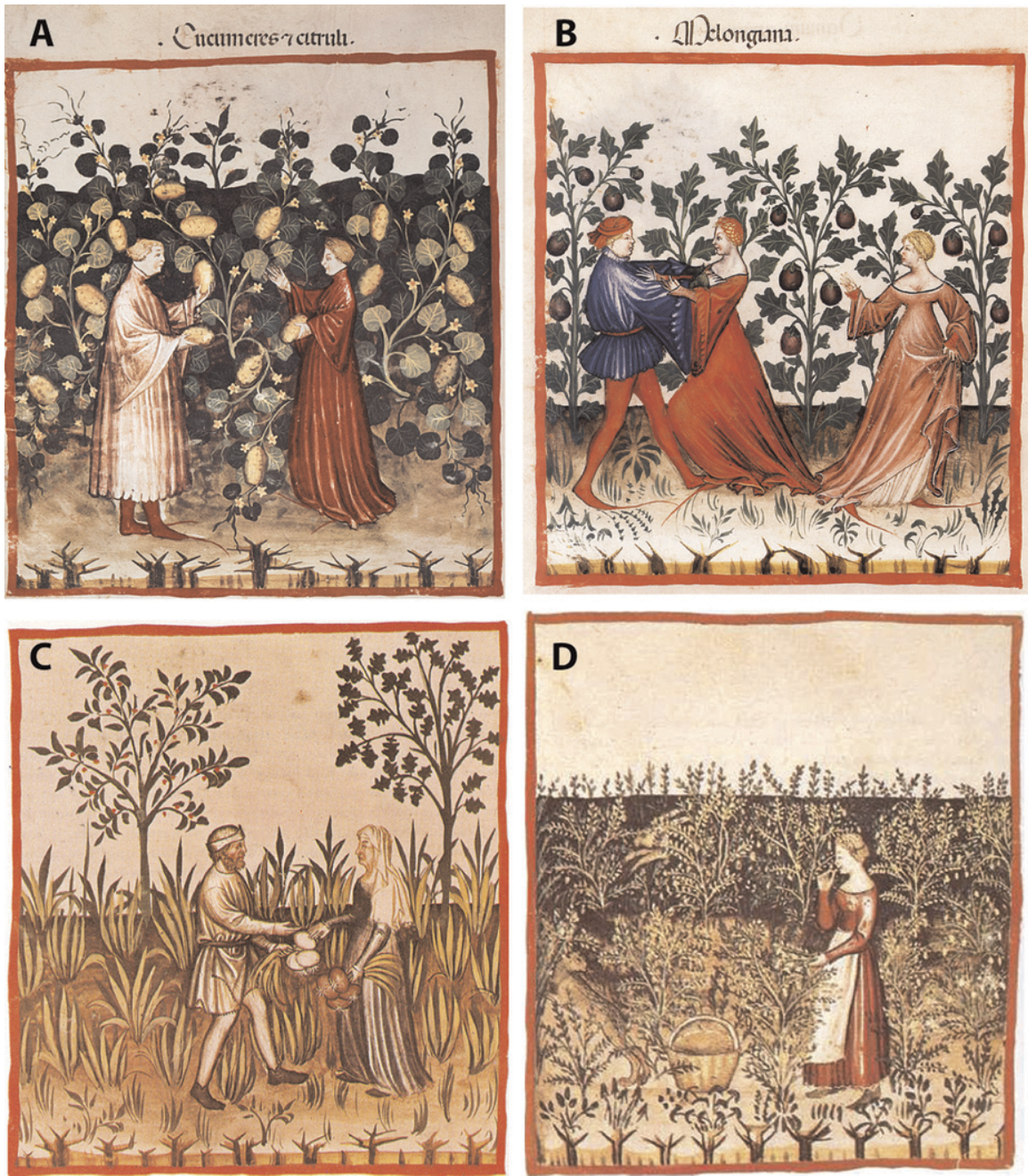

Fig. 2. Vegetables from the Vienna Tacuinum Sanitatis: (A) cucumber (Cucumis sativus) folio 23v; (B) eggplant/aubergine (Solanum melongena) folio 31v; (C) onion (Allium cepa) folio 25v; (D) chickpea (Cicer arietinum) folio 49r.

indicating similarity of culinary use of these two cucurbits. Although the illustration shows mature fruits that have turned yellow, the text advises green ones as best to consume. The text indicates that these fruits reduce burning fevers as a result of their cold, moist nature, are diuretic, and produce watery blood but cause stomachaches.

Eggplant. Domesticated in the IndoBurma area, eggplant has been an important crop in India as early as the third century $\mathrm{BCE}$ and has also an important place in Ayurvedic medicine (Daunay and Janick, 2007). It was domesticated in China by the first century BCE (Wang et al., 2008) and reached Europe in the medieval period (Daunay and Janick, 2007). In Figure 2B, a dramatic scene labeled Melongiana displays a fondling, amorous couple embracing in front of a row of eggplants while being severely admonished by an elegantly gowned lady. The illustration clearly suggests that eggplant had aphrodisiac properties. The plants bear a prolific crop of globular, purple fruits that appear similar to the present-day 'Black Beauty' market type. The undulate leaf laminae are depicted accurately, 
but the attractive purple flowers are absent. Ibn Butlan wrote that the young, non-bitter, medium-sized Persian fruits are best and are beneficial to blood vessels and for stomach weakness (Elkhadem, 1990).

Onion. Native to western Asia, onions were known in Egypt as early as 3200 BCE and were considered medicinal plants in India in the sixth century BCE (Simmonds, 1976). In Figure 2C, a laborer standing in a field of onions with one hand outstretched expecting payment offers a bunch of white bulbs to a middle-aged lady whose head is covered, suggesting she is married, and who already holds a bunch of purple bulbs. The illustration is labeled Cepe. The onions are neatly planted in rows in a garden that also contains two trees, one of which is a cherry. The text informs that onions were considered to be a diuretic, sharpen eyesight, promote coitus, generate milk in nursing mothers and semen in men, but cause headaches.

Chickpea. Native to western Asia, progenitors of the present-day chickpea have been known in India from 2000 BCE (Simmonds, 1976). Chickpea is now a traditional dryland crop in the Mideast. In Figure 2D a welldressed woman in a red gown protected by an apron is sampling pods in preparation for harvesting to a basket in the foreground. The crop appears spaced and planted. The text indicates that chickpeas are warm and humid to the first degree and the best are large-seeded. Chickpeas were supposed to increase sperm but to be noxious for the kidney and bladder.

\section{Fruits}

Grape. Old Word species of Vitis are indigenous to the south Caspian belt, Turkey, and the Balkans and were widely distributed to the Mediterranean basin (Janick, 2005) and were very early used to make wine. Grape is illustrated three times in this Tacuinum manuscript either listed as Uve, or for the production of verjuice (juice of immature grapes used in ancient and medieval cuisine), or as a symbol of fall, the time of wine-making. Depending on the images, the vines grow on trees or are trellised and bear black, purple, light red, or gold grapes. In Figure 3A, a man in red tights is getting ready to cut a cluster of purple grapes with a knife while a young woman in an aproned blue dress has just handed a basket of harvested grapes to a third man in a large barrel who is stomping them to extract their juice being collected in a wooden container below that will be used to prepare wine. Grapes were considered to cause thirst and cleanse the intestine.

Apple. The large, sweet-smelling domestic apple originated in Kazakhstan, migrated to Europe in antiquity, and was widely planted in the Roman era (Janick, 2005). In Figure 3B, labeled mala acetosa (sour apple), a courtier brings down large apples with a stick while an elegant lady carrying a basket watches in amazement. The best sour apples are very juicy, alleviate fainting and hepatitis but adversely affect joint articulation. Sweet apple (mala dulcis), shown in another illustration, strengthens the heart.
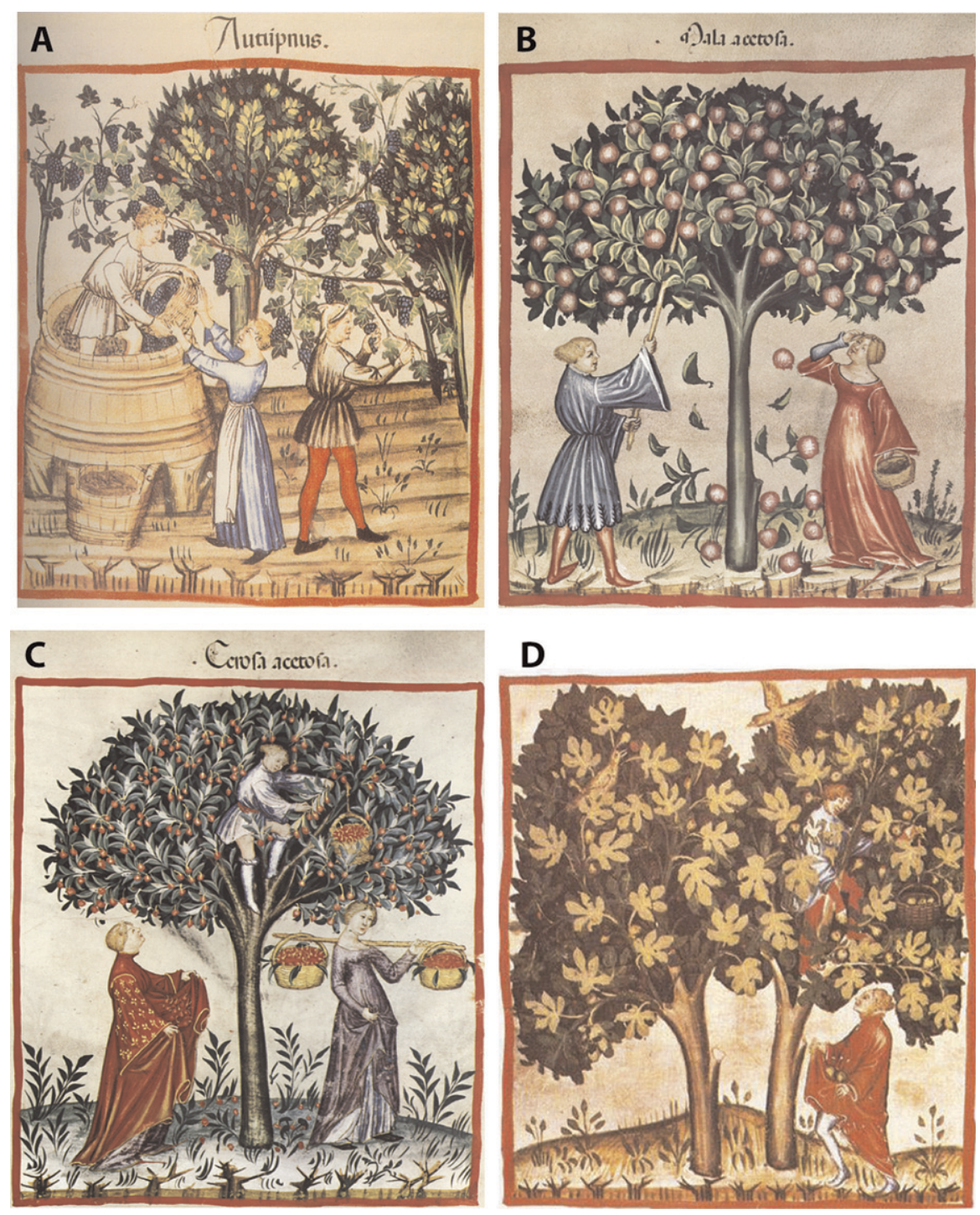

Fig. 3. Fruits from the Vienna Tacuinum Sanitatis: (A) grape (Vitis vinifera) folio 85r; (B) apple (Malus $\times$ domestica) folio 9r; (C) tart cherry (Prunus cerasus) folio 12r; (D) fig (Ficus carica) folio $4 \mathrm{v}$.

Cherry. The origin of sweet and tart cherries is central Europe and areas surrounding the Black Sea with sweet cherries occurring as far east as central Russia (Janick, 2005). In Figure 3C, tart cherries, labeled cerosa acetosa, are being harvested by a child who has climbed into the tree. A well-dressed lady opens her gown to catch fallen fruits and another elegant lady carries off two full baskets balanced on a pole. The very sour ones were considered best. The fruits were considered to cure bilious attack and dry out and settle upset stomachs. Cerosa dulcia, sweet cherry, which softens the stomach, is displayed in a separate image.

Fig. The common fig is a classic fruit of Mediterranean climates, and signs of cultivation are found in Neolithic sites (Zohary and Spiegel-Roy, 1975). Native to western Asia, figs were early introduced to India, where they have become a major fruit. In Figure 3D, a couple harvest figs; the young man in the tree throws down fruit to a lady companion in a red gown who catches the fruit in her skirt as she daringly shows her white-stockinged legs.
The text indicates that figs are warm and humid in the second degree and that whitepeeled kinds are optimum; figs cleanse the kidneys but inflate and fatten.

\section{Herbs}

Sage. This aromatic spice is found originating in southern Europe and Asia Minor (Simon et al., 1984). In Figure 4A, two welldressed ladies are shown picking a plant labeled Salvia growing in an enormous basket. Domestic sage was considered best and was good for paralysis and for the nerves, although slow to be digested.

Marjoram. This is a spice originating in northern Africa and southwestern Asia (Simon et al., 1984). Two elegantly gowned women tend marjoram (Marjorana) growing in a vase resting on a bench (Fig. 4B). Very small, aromatic marjoram was considered optimum, good for cold and moist stomachs, and to purify the blood. No noxious effects are described.

Dill. Native to southwestern Asia and India (Brickell and Cathey, 2008), this herb is well known in Ayurvedic medicine. The 


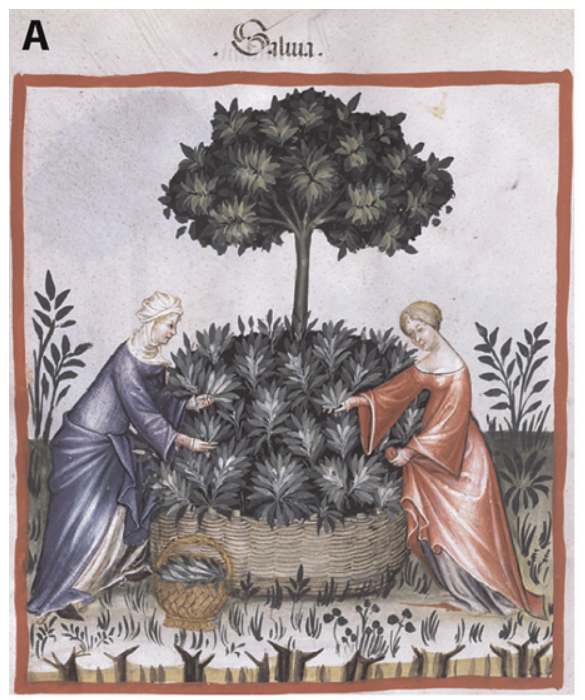

B
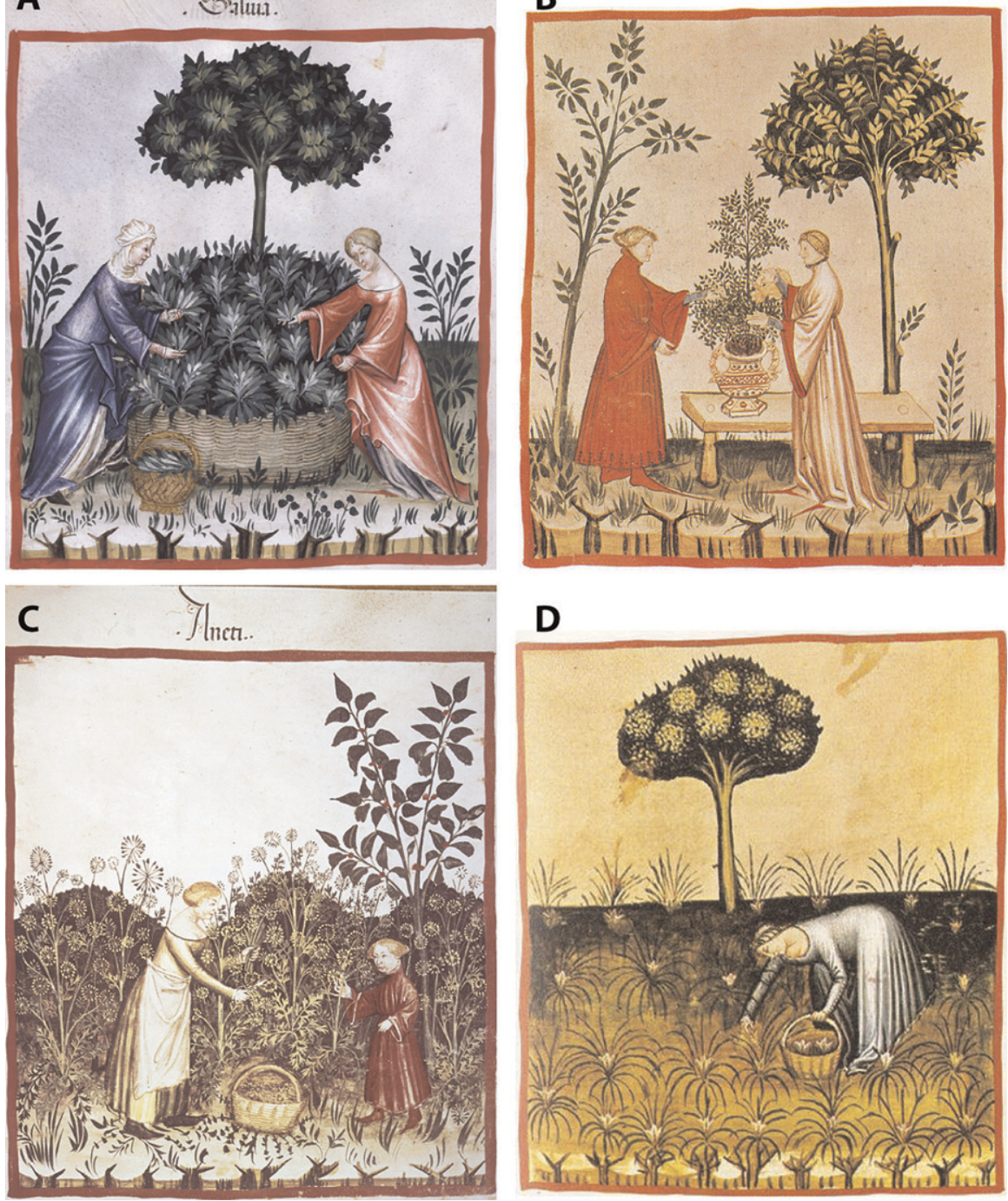

D

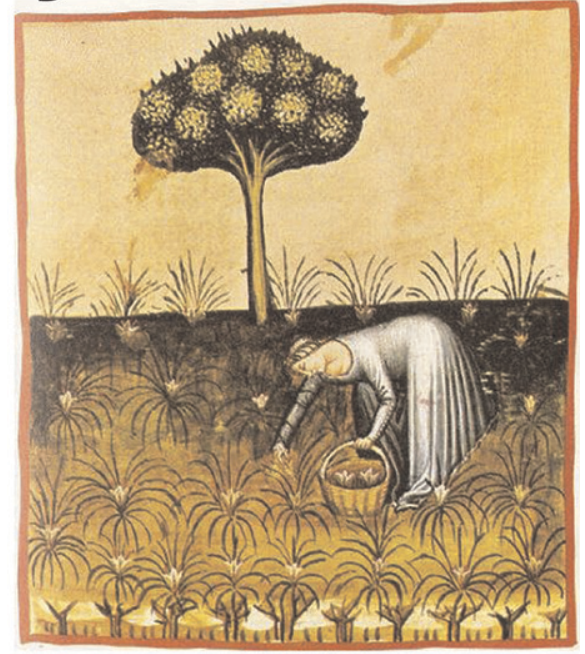

Fig. 4. Culinary herbs from the Vienna Tacuinum Sanitatis: (A) sage (Salvia officinalis) folio 37v; (B) marjoram (Origanum marjorana) folio 33v; (C) dill (Anethum graveolens) folio 32r; (D) saffron (Crocus sativus) folio 40v.

image in Figure 4C, labeled Aneti, shows a woman and a child harvesting dill in a weedy setting. The herb was considered best when green, fresh, and tender and was recommended for cold and flatulent stomachs, but was harmful to the kidneys and nausea-provoking.

Saffron. The saffron crocus, an ancient perennial herb, is known only in cultivation (Simon et al., 1984). Originating in southwestern Asia and perhaps native to Crete, the saffron crocus has long been cultivated in India. It is one of the most expensive spices on a weight basis; it takes 210,000 stigmas from 70,000 flowers to make $1 \mathrm{lb}$ of true saffron. The dried red three-branched stigmas are used in cooking as a colorant and seasoning. In Figure 4D a blue-gowned woman carrying a basket harvests flowers from saffron crocus (Crochus) neatly planted in rows. The text advises that saffron is hot in the second degree and dry in the first degree. The best is freshly cut, strong in color, and with a delicate scent. Saffron helps hearing but may induce vomiting.

\section{DISCUSSION AND CONCLUSION}

The familiar 16 horticultural crops illustrated in the Tacuinum manuscripts have little changed in their appearance over the centuries. The garden scenes resemble traditional horticulture practiced today in many parts of the world. Vegetables are shown harvested in gardens and fields from dense plantings, whereas fruit trees are pictured alone, suggesting that large orchards were uncommon. Aromatics such as sage and marjoram are generally depicted as growing in tended conditions (beds or pots), indicating that these plants were prized, whereas dill and saffron are shown in plantings. Peasants and feudal laborers are frequently pictured with the root and leafy vegetables, which were their basic food (Mane, 2006). Conversely, courtiers and nobles are more frequently found next to fruit vegetables such as cucurbits and eggplant, of relatively recent introduction in Europe (Daunay et al., 2008; Paris et al., 2009), which were probably considered fit for the elite. The upper class is also pictured next to fruit trees, produce reserved for the privileged (Mane, 2006). The medieval idea that the garden was a place for healing, relaxing, and physical and mental well-being was a premonition of modern horticultural therapy. Interestingly, all of the horticultural crops presented in the illustrated Tacuinum manuscripts were allocated physiological effects on the body and were fully part of the Western medieval pharmacopeia. Clearly, then as now, the population was concerned with general health and bodily functions, including flatulence, incontinence, and kidney stones, ill health, and sexuality. The brief text that accompanies each illustration in the Tacuinum provides information for balancing the beneficial and noxious effects of each plant.

Although the basis of modern medicine has completely changed from the ancient European and Asian philosophical concepts that date to antiquity, our attitudes toward our common horticultural crops are amazingly the same. All cultures, ancient, medieval, and modern, have come to the conclusion that horticulture is basic to a healthy life. However, modern knowledge of medicine and nutrition has changed our understanding of food through advances in biology, chemistry, and genetics and we now view foods in terms of calories, vitamins, antioxidants, polyphenols, anthocyanins, polysaccharides, proteins, and lipids (Goldman, 2003). However, it does appear as if all the analyses, ancient and modern, come to the same result: the horticultural crops we eat are sustaining, nutritious, healthy, and delicious. Although we no longer evaluate them on the basis of hot, cold, wet, or dry, or the effect on the "humors," some of the ancient feelings still persist. We still say colloquially "cool as a cucumber," we refer to pungent chili peppers as "hot," we associate spicy foods with passionate temperaments, and consider aroma and fragrance to affect our well-being. The classic cures of bloodletting and induced vomiting have been discarded, but purging is still being promoted by some under the guise of "clean colon." At times it may seem, as we investigate the healthful attributes of our food through chemistry, that we merely seek accreditation for our preferences. Although we smile indulgently at some extravagant claims of the ancients, it appears that in a number of cases their experience was prescient. For example, it turns out that horseradish does have a factor that affects urinary health (Shehata et al., 2008), and we have confirmed the healthgiving properties of the alliums (Desjardins, 2008) and crucifers (Monteiro and Rosa, 2008). Although not generally stated, some horticultural crops need to be considered carefully for detrimental effects as in the case of allergies ( $5 \%$ of the population is allergic to apples), excessive soluble fibers (such as persimmon), and toxic substances such as solanine in potato.

It is clear that the present-day emphasis on the connection between horticulture and health is an extension of ancient and medieval 
concerns. We suggest that our present understanding of nutrition will probably be considered naïve in the coming centuries and it may be that the approach for attributing health benefits to horticultural crops will likely be different from the present one. We predict, however, that the conclusions will be similar: horticultural crops are important for good health!

\section{Literature Cited}

Bertiz, A.A. 2003. Picturing health: The garden and courtiers at play in the late fourteenthcentury illuminated Tacuinum Sanitatis. PhD diss., University of Southern California, UMI 3116666.

Bovey, A. 2005. Tacuinum Sanitatis: An early Renaissance guide to health. Paul Holberton, London, UK.

Braziller, G. and L.I. Conrad. 1995. Scholarship and social context: A medical case from the eleventh-century Near East, p. 84-100. In: Bates, D. (ed.). Knowledge and the scholarly medical traditions. Cambridge University Press, Cambridge, UK.

Brickell, C. and H.M. Cathey. 2008. A-Z encyclopedia of garden plants. DK Publ., New York, NY.

Cogliati Arano, L. 1976. The medieval health handbook Tacuinum sanitatis. G. Braziller, New York, NY.

Daunay, M.-C., and J. Janick. 2007. History and iconography of eggplant. Chron. Horticult. 47: $16-22$
Daunay, M.-C., J. Janick, and H.S. Paris. 2009. Tacuinum Sanitatis: Horticulture and health in the late Middle Ages. Chron. Horticult. 49: 222-229.

Daunay, M.-C., H. Laterrot, and J. Janick. 2008. Iconograpy and history of Solanaceae: Antiquity to the 17 th century. Hort. Rev. 34:1-111 +31 plates.

Desjardins, Y. 2008. Onion as a nutraceutical and functional food. Chron. Horticult. 48:8-14.

Elkhadem, H. 1990. Le Taqwim al Sihha (Tacuini Sanitatis) d'Ibn Butlan: Un traité médical du $\mathrm{XI}^{\mathrm{e}}$ siècle. Peeters, Louvain.

Goldman, I.L. 2003. Recognition of fruits and vegetables as healthful: Vitamins, minerals, fiber, and phytonutrients. HortTechnology 13: $1-6$.

Hoeniger, C. 2006. The illuminated Tacuinum Sanitatis manuscripts from northern Italy ca. 1380-1400: Sources, patrons, and the creation of a new pictorial genre, p. 51-81. In: Givens, J.A., K.M. Reeds, and A. Touwaide (eds.). Visualizing medieval medicine and natural history, 1200-1550. Ashgate, Aldershot, UK.

Janick, J. 2005. The origins of fruits, fruit growing, and fruit breeding. Hort. Rev. (Amer. Soc. Hort. Sci.) 25:255-320.

Janick, J., M.-C. Daunay, and H.S. Paris. 2009. Horticulture and health: Ancient and medieval views. Souvenir. Intl. Conference on Horticulture. 9-12. November 2009, Bangalore, India. p. 23-34.

Mane, P. 2006. Le travail à la campagne au Moyen Âge. Étude iconographique. Picard, Paris, France.
Monteiro, A.A. and E. Rosa. 2008. Caldo verde: A story of Portuguese brassicas. Chron. Horticult. 48:9-11.

Opsomer-Halleux, C. 1991. L'art de vivre en santé, images et recettes du Moyen Âge: Le Tacuinum sanitatis, manuscript 1041 de la Bibliothèque de L'Université de Liège. Editions Du Perron, Liège.

Paris, H.S., M.C. Daunay, and J. Janick. 2009. The Cucurbitaceae and Solanaceae illustrated in medieval manuscripts known as the Tacuinum Sanitatis. Ann. Bot. (Lond.) 103:1187-1205.

Segre Rutz, V. 2002. Historia plantarum, erbe, oro e medicina nei codici medievali, volume di commento. Franco Cosimo Panini, Modena, pp. $123-170$.

Shehata, A., R.M.S. Mujlwa, M. Babadoost, M. Uchanski, M.A. Norton, R. Skirvin, and S.A. Walters. 2008. Horseradish: Botany, horticulture, breeding. Hort. Rev. (Amer. Soc. Hort. Sci.) 35:221-261.

Simmonds, N.W. (ed.). 1976. Evolution of crop plants. Longman, New York, NY.

Simon, J.E., A.F. Chadwick, and L.E. Craker. 1984. Herbs: An indexed bibliography. Archon Books, Hamden, CT.

Wang, J.-X., T.G. Gao, and S. Knapp. 2008. Ancient Chinese literature reveals pathways of eggplant domestication. Ann. Bot. (Lond.) 102:891-897.

Witthoft, B. 1978. The Tacuinum Sanitatis: A Lombard panorama. Gesta 17:49-60.

Zohary, D. and P. Spiegel-Roy. 1975. Beginning of fruit growing in the Old World. Science 187: 319-327. 